International Journal of Current Advanced Research

ISSN: O: 2319-6475, ISSN: P: 2319 - 6505, Impact Factor: SJIF: 5.995

Available Online at www.journalijcar.org

Volume 6; Issue 4; April 2017; Page No. 3175-3176

DOI: http://dx.doi.org/10.24327/ijcar.2017.3176.0216

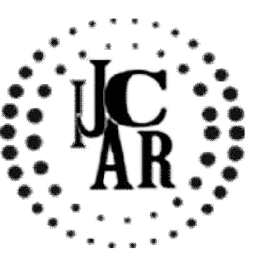

Research Article

\title{
CYTOTOXICITY OF WALNUT OIL ON ORAL CANCER CELL LINES
}

\author{
Induja M.P., Gayathri R and Vishnupriya V
}

Saveetha Dental College and Hospitals, Poonamalle High Road, Chennai

\begin{tabular}{l}
\hline A R T I C L E I N F O \\
\hline Article History: \\
Received $11^{\text {th }}$ January, 2017 \\
Received in revised form $19^{\text {th }}$ February, 2017 \\
Accepted $22^{\text {nd }}$ March, 2017 \\
Published online $28^{\text {th }}$ April, 2017 \\
\hline
\end{tabular}

Key words:

Walnut Oil, Oral Cancer Cell

\begin{abstract}
A B S T R A C T
Aim: To assay cytotoxic activity of walnut oil on oral cancer cell line

Objective: This study is to analyse the cytotoxicity of walnut oil on oral cancer cell line by DNA fragmentation. The cytotoxicity of walnut oil on oral cancer cell line is to be studied.

Background: Walnut is unique because they have a perfect balance of $n-6$ and $n-3$ polyunsaturated fatty acids. The increasing market demand of walnut lipids results in the large amount of the oil extraction residue. The walnut residue is rich in nutritional proteins, and the uneconomic use of the by-product discouraged the development of walnut industry. Anticancer peptides have recently received attention as alternative chemotherapeutic agents that overcome the limits of current drugs.

Reasons: Oral cancer as become very prevalent nowadays. This research was done to experiment if walnut oil can kill oral cancer cell line.
\end{abstract}

Copyright $₫ 2017$ Induja M.P et al. This is an open access article distributed under the Creative Commons Attribution License, which permits unrestricted use, distribution, and reproduction in any medium, provided the original work is properly cited.

\section{INTRODUCTION}

Cytotoxicity is the quality of being toxic to cells.Types of venom are some examples of toxic agents or immune cell.Chemotherapy as a treatment of cancer relies on the ability of toxic agents to damage cells or to killcells which are reproducing; this preferentially targets rapidly dividing cancer cells(8). Antibody dependent cell mediated cytotoxicity describes the cell killing ability of certain lymphocytes, which requires which required the target cells being marked by the antibody. Cytotoxicity assays are widely used by the pharmaceutical industry to screen for cytotoxicity in compound libraries.Cytotoxicity can also be measured by sulforhodamineB assay, WST assay, etc(9).

Walnut oil is an oil extracted from walnut (juglans regina). Each $100 \mathrm{~g}$ of oil contains $63.3 \mathrm{~g}$ of polyunsaturated fatty acid, $22.8 \mathrm{~g}$ monounsaturated fatty acid and $9.1 \mathrm{~g}$ saturated fatty acid. It contains no cholesterol .Unlike most nuts that are high in monounsaturated fatty acid. Walnut oil has large amount of polyunsaturated fatty acid. Particularly, alpha-linolenic acids, linolenic acids (1).

There are two types of walnut oil they are cold pressed and refined.Cold pressed walnut oil is actually more expensive due to the loss of higher percentage of oil.Refined walnut oil expeller pressed and saturated with the solvent to extract the highest percentage of the oil available in the nut meal. Walnut oil is very much rich in vitamins and minerals.(2)

*Corresponding author: Induja M.P

Saveetha Dental College and Hospitals, Poonamalle High Road, Chennai

\section{MATERIALS AND METHODS}

\section{Procurement of oil}

The walnut oil was procured from Cyrus India Ltd. And further analysis was done using this oil.

Maintainence of $\boldsymbol{k b}$ cell line: The vial containing KB cell lines where procured from national centre for cell sciences (NCCS), Pune.The Oral cancer cells were seeded in 24 Welles plate and kept in $\mathrm{CO} 2$ incubator.

\section{Treatment of kb cell lines with drug (walnut oil)}

The cells were treated with walnut oil in three different concentrations $(100 \mu \mathrm{l}, 200 \mu \mathrm{l}, 300 \mu \mathrm{l})$ and left along for 24 hours.

\section{Isolation of Genomic DNA}

The Cells were placed in a $37^{\circ} \mathrm{C}$ water bath. It was continuously until the medium thawed. Then it was centrifuged at 1000rpm for 5 minutes at room temperature (5). The supernatant was discarded and cells were washed with fresh medium to remove residual DMSO(Dimethyl Sulphoxide) which is an important polar aprotic solvent that dissolves both polar and non-polar compounds and is miscible in a wide range of organic solvents as well as water.The cell pellet was re-suspended in 3ml of of DMEM(Dulbecco's Modified Eagle's Medium: a composition that helps in maintaining mammalian cell culture) with 10\% FBS (Fetal Bovine Serum which helps in easier coagulation of cells)(6). It was then incubated in a $\mathrm{CO} 2$ incubator at a humidified $37^{\circ} \mathrm{C}$. The medium was changed every $2-3$ days or when ph indicator (e.g. Phenol red) in medium changed colour. The culture was kept in a medium with $10 \%$ FBS until cell 
line were re-established. The treated cells were then subjected to DNA fragmentation. (4)

\section{MTT Assay}

The MTT assay (Mossman, 1983) ${ }^{6}$ is based on the ability of live but not dead cells to reduce a yellow tetrazolium dye to a purple formazan product. Cells were maintained in DMEM medium, supplemented with 10\% Fetal Bovine Serum, at $37^{\circ} \mathrm{C}$ in humidified atmosphere with $5 \% \mathrm{CO}_{2}$. The cells were plated in 96 well flat bottom tissue culture plates at a density of approximately $1.2 \times 10^{4}$ cells /well and allowed to attach overnight at $37^{\circ} \mathrm{C}$. The medium was then discarded and cells were incubated with different concentrations of the samples $(100,200 \& 300 \mu \mathrm{g})$ for 24 hours. After the incubation, medium was discarded and $100 \mu \mathrm{l}$ fresh medium was added with $10 \mu \mathrm{l}$ of MTT $(5 \mathrm{mg} / \mathrm{ml})$. After 4 hours, the medium was discarded and $100 \mu \mathrm{l}$ of DMSO was added to dissolve the formazan crystals. Then, the absorbance was read at $570 \mathrm{~nm}$ in a microtitre plate reader. Cyclophosphamide was used as a positive control.

Cell survival was calculated by the following formula:

Viability $\%=($ Test OD/ Control OD) X 100

Cytotoxicity $\%=100$ - Viability $\%$.

\section{RESULTS AND DISCUSSION}

Cytotoxicity analysis using various concentrations of walnut oil (100, 200, 300 micrograms) was performed. The viability of the KB cell lines shows a gradual decrease as the concentration of the walnut oil is increased. This exhibits the Cytotoxicity of walnut oil extract with increasing concentration. (10)

Oral cancer is one of the major worldwide threats to public health.It is associated with severe morbidity and long-term survival is less than $50 \%$ despite advances in the treatment (surgery, radiation, and chemotherapy.The survival of the patients remains very low, mainly due to their high risk of developing a second primary cancer. Therefore, the early detection and prevention of oral cancer and pre malignancy are quite important. The use of synthetic drugs and radiation not only destroy cancer cells but they also cause damage to other cells thereby causing delayed wound healing. Therefore in near future new approaches can be initiated by using walnut oil tempered with other natural compounds may be of great promise in finding a sure cure for cancer patients and can be used to create further scope in the discovery of chemopreventive drugs(7).

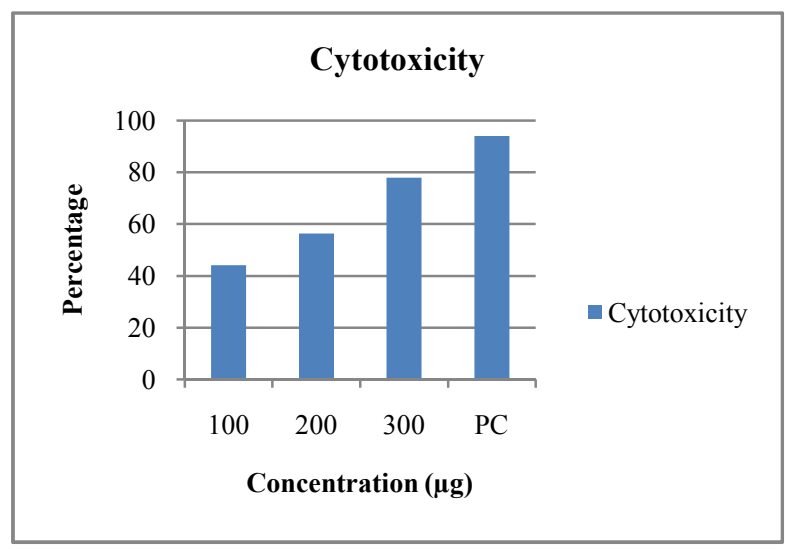

\section{CONCLUSION}

From the above experiment and research it is proven that walnut oil has the potential to treat oral cancer. walnut oil is the most commonly available product of Juglans regia and is easily available in the market. Though research is still proceeding in various parts of the world to make use of this plant extract to treat cancer, oral-cancer in specific, there is less awareness among the masses(3).In near future the phytochemical properties of walnut oil may be used to design anti-cancer drugs. Also the medicinal property of the various natural herbs should be explored because than the other chemotherapeutic drugs, they don't affect the normal and healthy cells and they don't cause any side effects.

\section{References}

1. D.J. Undersander, E.A. Oelke, A.R. Kaminski, J.D. Doll, D.H. Putnam, S.M. Combs, and C.V. Hanson (1990). "Walnut". Alternative Field Crops Manual.

2. "Walnut Oil for Nails: Natural Care for Your Perfect Manicure". Body (personal) care.

3. P. E. Petersen, "Oral cancer prevention and control-the approach of the World Health Organisation," Oral Oncology, vol. 45, no. 4-5, 2009, 454-460.

4. T. Tanaka, "Chemoprevention of oral carcinogenesis," European Journal of Cancer Part B: Oral Oncology, vol. 31, no. 1, 1995, 3-15.

5. T. Tanaka, "Effect of diet on human carcinogenesis," Critical Reviews in Oncology/Hematology, Vol. 25, no. 2, , 1997, 73-95.

6. T. Tanaka, "Chemoprevention of human cancer: biology and therapy," Critical Reviews in Oncology/Hematology, vol. 25, no. 3, 139-174, 1997.

7. Rajkumar Paul, Murari Prasad \& Nand K. Sah (2011) Anticancer biology of Azadirachta indica L (neem): A mini review, Cancer Biology \& Therapy, 12:6, 467476, DOI: $10.4161 /$ cbt.12.6.16850.

8. Mosmann T. Rapid colorimetric assay for cellular growth and survival: application to proliferation and cytotoxicity assays. J Immunol Methods. 1983; 65:5563. [PubMed]

9. Kumbhare MR, Guleha V, Sivakumar T. Estimation of total phenolic content, cytotoxicity and invitro antioxidant activity of stem bark of Moringa oleifera. Asian Pac J Trop Dis. 2012;2(2):144-150.

10. Mahavorasirikul W, Viyanant V, Chaijaroenkul W, Itharat A, Na-Bangchang K. Cytotoxic activity of Thai medicinal plants against human cholangiocarcinoma, laryngeal and hepatocarcinoma cells in vitro. BMC Complement Altern Med. 2010; 10:55. [PubMed] 